\title{
Festividade e erotismo nas cantigas de Pero Meogo
}

\author{
André Luis Nepomuceno \\ Centro Universitário de Patos de Minas
}

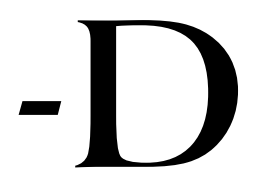

igades, filha, mya filha velida,

porque tardastes na fontana fria.

Os amores ey.

Digades, filha, mya filha louçana, porque tardastes na fria fontana.

Os amores ey.

- Tardey, mya madre, na fontana fria, cervos do monte a áugua volvian.

Os amores ey.

Tardey, mya madre, na fria fontana, cervos do monte volvian a áugua.

Os amores ey.

- Mentir, mya filha, mentir por amigo, nunca vi cervo que volvess'o rio.

Os amores ey.

Mentir, mya filha, mentir por amado, nunca vi cervo que volvess'o alto.

Os amores ey.

A cantiga acima transcrita, ${ }^{1}$ que faz parte do imenso acervo dos trovadores galego-portugueses medievais, compõe o repertório das nove

\footnotetext{
${ }^{1}$ A edição que uso para a cantiga "Digades, filha, mya filha velida", de Pero Meogo, está em Azevedo Filho (1974, p. 79), que propõe lições a partir das variantes dos manuscritos apógrafos, com crítica geral do texto e fac-símile. Em anexo, deixo ainda a versão de Cohen (2003, p. 425), de cuja edição extraí os textos das cantigas de outros trovadores transcritas neste ensaio, e uma imagem facsimilar da cantiga no códice COD. 10991, do Cancioneiro da Biblioteca Nacional. Para as citações das cantigas de Meogo, sigo as lições de Azevedo Filho.
} 
cantigas de amigo de Pero Meogo, jogral que poetou nos tempos do rei D. Dinis, em Portugal. Suas poucas cantigas que sobreviveram (se é que ele escreveu outras), conforme revelam os manuscritos, figuram como as entradas 789-797, do Cancioneiro da Biblioteca Vaticana, e 1184-1192, do Cancioneiro da Biblioteca Nacional, ambos os documentos copiados, conforme se tem notícias, apenas no séc. 16, por iniciativa do humanista Angelo Colocci. ${ }^{2}$ As diversas edições e transcrições das nove cantigas de Meogo, em suas variantes ao longo dos séculos, têm dificultado a fixação do texto (o que, de resto, não é diferente dos problemas intrínsecos aos códices medievais), de tal forma a tornar eventualmente ambíguas algumas passagens (AZEVEDO FILHO, 1974, p. 15-33), porém não o suficiente para apagar os traços de originalidade de sua literatura, num tempo em que trovadores repetiam à exaustão temáticas e estruturas formuladas pela "Arte de Trovar", contida no Cancioneiro da Biblioteca Nacional. A cantiga "Digades filha", bem como todo o corpus literário de Pero Meogo, mantém a típica estrutura das cantigas de amigo, conforme visivelmente se percebe pelo tema e pelas vozes do discurso.

As notícias que se tem sobre Pero Meogo são bastante escassas, o suficiente para tornar duvidoso qualquer palpite sobre informação biográfica. A respeito dele, Lanciani e Tavani (1993, p. 54-55), no Dicionário da literatura medieval galega e portuguesa, informam que se trata de um

jogral galego do século XIII de quem nada sabemos. Nos Cancioneiros está escrito Meogo (V) ou M?ogo (B). O nome Pero Mõogo aparece nos documentos galegos do séc. XIII, mas não se pode inferir disso que o jogral fosse um clérigo de Banga (Ourense), relacionado com o mosteiro de Toxos-Outos, nem de Monfero ou Sanfins, nem um

\footnotetext{
${ }^{2} \mathrm{O}$ Cancioneiro da Biblioteca Nacional (Colocci-Brancuti) pertence à Biblioteca Nacional de Lisboa, onde tem a cota COD. 10991, e possui 355 fólios numerados, com anotações de Colocci (ver Cancioneiro da Biblioteca Nacional: ColocciBrancuti. 1. Reprodução facsimilada. Lisboa: Biblioteca Nacional/ Imprensa Nacional - Casa da Moeda, 1982). Correia, Dionísio e Gonçalves (in CASTRO, 2001, p. 109) comentam que "da responsabilidade do humanista são numerosas correções aos textos, abundantes sinais e interessantes notas de caráter lingüístico". Nele as cantigas de Pero Meogo ocupam os fólios 252-254. O Cancioneiro da Biblioteca Vaticana pertence à Biblioteca Apostólica Vaticana (como códice Vat. lat. 4803), que foi parcialmente transcrito pelo mesmo Colocci, que igualmente o marcou com apostilas marginais.
} 
notário de Santiago de Compostela. Possivelmente é coetâneo de Nuno Fernandez Torneol e Martim Codax e anterior a D. Denis, que seguiu a cantiga n. 5 .

A identificação do nome de Pero Meogo como clérigo, ou como monge, veio por sugestão de Carolina Michaëlis de Vasconcellos (1990, vol. II, p. 622) que, ao fazer um rastreamento das "diversas camadas sociaes de que sahiram os trovadores", assim formula: "Pero Meogo, jogralmonge, se a minha suspeita de Móogo provir de móago < monãchus for justificada". É a mesma Carolina Michaëlis que afirma que, "entre os vinte e seis que escreveram exclusivamente cantares de amigo, quatorze são populares" (VASCONCELLOS, p. 627, grifo meu), dentre eles, o próprio Pero Meogo (Moogo). Leodegário de Azevedo Filho (1974, p. 18), por sua vez, recusa a identificação de Meogo com um monge, dizendo que "nenhuma razão realmente séria foi aduzida para justificar a substituição de Meogo (forma claríssima nos manuscritos) para Moogo", e que "o que há de certo é o teor popular de sua poesia, o que nos levar a admitir que tenha pertencido à classe dos jograis. Se foi monge ou não, isso jamais ficou provado" (VASCONCELLOS, p. 627). Por fim, Hernani Cidade (1972, p. xv), em breve compilação de cantigas de amigo dos trovadores portugueses, identifica Pero Meogo, ou Moogo, apenas como "trovador burguês".

De qualquer forma, afora as dúvidas sobre a biografia do jogral (que, nesse caso, possivelmente pouco contribuem para a elucidação da obra), é importante notar que as nove cantigas que compõem o seu corpus, embora simples cada uma delas e submetida à típica estrutura da arte de trovar, no todo formam um grupo literariamente coeso, harmonioso, em que a seqüência - ordenada da mesma forma nos dois manuscritos estabelece uma curiosa "narrativa", com tempo, espaço e ação. Embora considere "narrativa", nesse caso, uma definição imprecisa, pelas razões que devo expor, prefiro mapear inicialmente a manipulação de tempo, espaço, ação e personagens, proposta por Meogo, para pensar o significado desse todo e as complexidades que envolvem a cantiga em análise que, em ambos os manuscritos, é a última do conjunto.

Embora no todo resumam um engenho de ousadias originais, as cantigas de Pero Meogo põem em cena temáticas, situações e linguagens bastante comuns ao universo da lírica trovadoresca. Em seqüência, elas assumem um sentido novo, ousado. Os personagens que compõem esse drama são os mesmos que aparecem nos mais diversos textos de outros trovadores e jograis da época: a menina apaixonada (a típica voz feminina 
dos cantares de amigo), a mãe repressora que vigia suas atitudes, e o namorado, elemento externo que vem desequilibrar uma ordem afetiva do ingênuo mundo da menina.

Na cantiga I, "O meu amig' a que preyto talhey", articula um diálogo razoavelmente tenso entre a jovem e a mãe, em que apenas a primeira fala e expõe um conflito sentimental, dizendo que marcara um encontro com o namorado na fonte, "u os cervos van bever", mas que não irá por obediência à mãe. Por fim, a jovem diz que irá mentir ao amigo, não por vontade própria, mas por medo da mãe ("mays mentir-lh'ey, com vosso pavor"), mesmo sabendo que o namorado ficará indignado. Note-se que a cantiga já trabalha com os elementos alegóricos típicos desse jogral português, como a fonte, o cervo e outras imagens que compõem o acervo imaginário de Meogo. Esses elementos irão se acentuar nas cantigas seguintes, contribuindo para fixar no ouvinte um conjunto de símbolos marcantes, no plano inconsciente, em que o cervo será um símbolo do sexo masculino, portanto, do namorado que ainda deverá entrar em cena, e a fonte será o elemento feminino, receptivo, e ao mesmo tempo, o espaço do encontro amoroso. ${ }^{3}$

Na cantiga II, "Por muy fremosa que sanhuda estou", o jogral irá nos colocar diante de uma primeira ironia, ou antes, de uma primeira situação de humor: sabemos que as promessas da menina de não ver o namorado, na cantiga I, eram apenas mentira estratégica de mocinha namoradeira. Agora, numa espécie de monólogo confessional, de que a mãe, portanto, não participa, ela admite que foi à fonte, sim, encontrar o namorado, mas voltou "sanhuda" (irritada), por saber que ele não estava lá. É o primeiro desencontro que deverá apenas prorrogar o clímax, envolvido pela sedução e pela expectativa.

\footnotetext{
${ }^{3}$ Os elementos do imaginário simbólico das cantigas de Pero Meogo foram decifrados, com bastante propriedade, por Azevedo Filho (1974, pp. 92-97; e 2000, pp. 21-32). Ver também Lanciani e Tavani (1993, p. 55). Correia, Dionísio e Gonçalves (in CASTRO, 2001, p. 125), a respeito do cervo como alegoria do elemento masculino, comentam: "sabe-se que o cervo era objecto de cultos dos Celtas, que é identificado com o amante na Bíblia, na Eneida e na língua árabe. O cervo que revolve a água é, por outro lado, tema que se encontra em todo o folclore europeu [...]. Mas, dentro da lírica galego-portuguesa não só as cantigas de Pêro Meogo falam deste animal: podemos vê-lo referido também numa cantiga de Vidal de Elvas e noutra de Johan Mendiz de Briteyros. Nestes autores, porém, o motivo aparece apenas esporadicamente".
} 
A cantiga III, "Tal vay o meu amigo, con amor que lh'eu dey", uma espécie de extensão do drama confessional da cantiga II, torna a mãe agora quase uma confidente do sentimento de perda da menina, que então explica os motivos de o amigo não ter ido ao encontro marcado na fonte. Ele viajou pelo mar, por razões que desconhecemos (e jamais saberemos ao certo), e como "cervo ferido", no mar também morrerá de amores, se a jovem não se dedicar a ele em pensamentos. A mãe, então, assume o discurso, em tom de conselheira, dizendo à menina que tome cuidado porque também ela, quando jovem, fora vítima de um namorado que simulou amores e "que se fez coitado, por guaanhar de min". O motivo da viagem marítima levou Segismundo Spina (apud Azevedo Filho, 1974, p. 52) a considerar que se trata de um "jogral marinheiro". A cantiga III, pela temática exposta, é uma das mais convencionais do corpus: o tema da jovem que chora a distância do amigo foi celebrado por uma imensa maioria dos trovadores galego-portugueses, e isso parece retratar uma condição histórica das mulheres medievais da Península Ibérica que, como lembra Rodrigues Lapa (1970, p. 112), tinham que conviver com a "ausência do namorado, que tinha ido lidar com os mouros, em defesa da terra". Essa "tradução poética de uma realidade social", para usar uma outra expressão de Rodrigues Lapa, pode retratar uma situação específica, percebida em contexto mais amplo (embora o texto de Pero Meogo não o especifique), em que o jovem abandona a história de amor, para o envolvimento com a guerra, no caso, as expedições das Cruzadas, e deixa em saudades a sua amiga. Outros trovadores retratam jovens namoradas que comentam a ausência do amigo, que assumiu compromissos bélicos com o rei, como nesta cantiga de Pero da Ponte:

Pois meu amigo en cas del rei me tarda tan longa sazon,

ou ainda nesta outra do mesmo trovador:

Foi s'o meu amigo daqui na oeste, por el rei servir, e nunca eu depois dormir pudi, mais ben tenh'eu assim: que, pois m'el tarda e non ven, el rei o faz, que mho deten (in COHEN, 2003, p. 292-293). 
As viagens marítimas dos namorados, ${ }^{4}$ em que os reis (símbolo do chamado para a guerra) serviam como espécie de "rivais" das jovens, roubando-lhes os amigos, funcionam no caso da cantiga III de Pero Meogo, como exemplo típico das situações sentimentais de jovens mulheres da Idade Média peninsular, como revela o verso em que o namorado é "come cervo ferido de monteyro d'el rey".

A cantiga IV, "Ay cervos do monte, vin-vos preguntar", é também uma extensão da cantiga III, elaboradora dos estados sentimentais melancólicos da amiga que agora, a exemplo de tantos modelos célebres (como os textos de D. Dinis e Martim Codax), busca a natureza como refúgio e confidente. Os cervos do monte ${ }^{6}$ que ouvem os lamentos da menina, elementos recorrentes nas cantigas de Pero Meogo - conforme

${ }^{4}$ Paio Gomes Charinho, por exemplo, celebrou o lamento da viagem marítima ("As frores do meu amigo/ briosas van no navio,/ e van s'e as frores/ daqui ben con meus amores/ idas son as frores"), ou o alívio da menina que descobre que o namorado já não vai mais servir o rei em guerra pelo mar: "Disseron m'oj', ai amiga, que non/ é meu amig'almirante do mar" (in COHEN, 2003, p. 297 e 299).

${ }^{5}$ Veja-se ainda outro exemplo do rei que convoca o soldado-namorado, numa cantiga de Roi Queimado: "- Madre, quer'oj eu ir veer/ meu amigo, que se quer ir/ a Sevilha el rei servir;/ ai madre, ir lo ei veer" (in COHEN, Op. cit., p. 333). Outras circunstâncias de saudade amorosa, nas cantigas dos cancioneiros galego-portugueses, expõem o quadro do "amigo traidor", que abandonou a namorada, para se dedicar a outra, como mostram (para usar apenas um exemplo dentre tantos) esses versos de João Garcia: "o meu amigo, que eu sempr'amei,/ des que o vi, mui mais ca min nen al,/ foi outra dona veer por meu mal [...]" (idem, p. 305). ${ }^{6} \mathrm{Na}$ edição de Cohen (Op. cit., p. 420), bem como em diversas outras edições das cantigas de Pero Meogo, lê-se "Ai cervas do monte", não se seguindo a lição dos manuscritos: "Ai cervas do monte, vin vos preguntar:/ foi s'o meu amigo, e, se alá tardar/ que farei velida?". Em geral, os editores substituem cervos por cervas para combinar com velidas do 3. verso, mas como Cohen registra velida (numa intenção de que velida se refira à própria voz da jovem?), a substituição não faz sentido, pelo menos aparentemente. Azevedo Filho (1974, p. 57), seguindo Rodrigues Lapa, identifica como improcedente a troca de cervos por cervas, esclarecendo que "no texto, há uma invocação aos cervos do monte (como símbolo permanente nas cantigas), que é independente do vocativo: velidas", o que sugere, portanto, dupla invocação, aos cervos e às amigas velidas, pressupostas no vocativo. 
já se disse - parecem evocar, pelo menos como lembrança inconsciente, a presença imaginária do amigo.

A cantiga V, "Levou-s' a velida, levou-s' a louçana", 7 é surpreendente em todos os sentidos, porque põe em cena, às súbitas, o encontro amoroso que ainda não esperávamos: um narrador em terceira pessoa (é a única cantiga que apresenta outra voz discursiva além dos personagens) nos conta que a menina fora lavar os cabelos na fonte, onde os cervos volviam as águas, e que por ali passou o seu amigo, de modo imprevisto, o que, portanto, sugere efetivamente o encontro dos amantes, já tão antecipado pela trama. Azevedo Filho (1974, p. 64) sugere possibilidades simbólicas no nível paradigmático do discurso, em que as garcetas (madeixas, cabelos longos) são símbolo da virgindade e o cervo, como de costume, símbolo do elemento masculino. O tema do encontro amoroso, permeado de sugestões eróticas, em que a jovem lava os cabelos na fonte e é surpreendida pelo amado foi também pensado por João Soares Coelho, numa cantiga em tudo semelhante à de Pero Meogo:

Fui eu, madre, lavar meus cabelos

a la fonte e paguei m'eu deles

e de mi, louçana

Fui eu, madre, lavar mhas garcetas

a la fonte e paguei m'eu delas

e de mi, louçana

A la fonte e paguei m'eu deles;

aló achei, madr', o senhor deles

e de mi, louçana

E, ante que m' eu d'ali partisse,

fui pagada do que m'ele disse

e de mi, louçana (in COHEN, Op. cit., p. 174).

Na cantiga VI, "Enas verdes ervas", extensão dramática da anterior, a jovem parece conversar com o amigo, na verdade em monólogo, já que ele não responde às suas considerações, num cenário romântico que lembra as carícias posteriores ao encontro amoroso. O fato de ela

\footnotetext{
${ }^{7}$ Para uma análise da cantiga V de Pero Meogo, identificada com a cantiga "Levantou-s'a velida", de D. Dinis, ver Sánchez (in http://www.auladeletras.net/ revista/articulos/serna.pdf).
} 
conversar com o namorado depreende-se pelo refrão em forma de vocativo, "meu amigo", que fecha todas as estrofes. Azevedo Filho (1974, p. 68) comenta que "já agora, pela sugestão dos símbolos, os dois estão juntos e ela se dirige a ele, diretamente".

A cantiga VII quebra a ambientação romântica das duas anteriores, e volta à cena dos diálogos entre mãe e filha, agora em conversa mais transparente, em que a filha sugere o desejo de compromisso, pensando que o namorado poderá conversar com sua mãe, para que possivelmente, juntos, acertem a condição de seu namoro. A menina diz que irá, de novo, à fonte, porque recebeu chamado do amigo, em atitude ousada e desrespeitosa dos códigos morais em que fora formada. Os versos "se ousará meu amigo/ ante vós falar comigo" sugerem os arroubos da menina destemida que incita o namorado a gestos de ousadia.

A cantiga VIII, "Fostes, filha, eno baylar", é certamente a mais carregada de alusões simbólicas e eróticas: quem assume o discurso é a mãe que, decepcionada com a filha ("ao meu pesar") revela o conhecimento de seus segredos, mostrando a ela as evidências de um vestido rasgado ("e rompestes i o brial"), que provam o encontro erótico dos amantes. Azevedo Filho (2000, p. 29-30; 1974, p. 77) já decifrara que o vestido rasgado é símbolo da perda da virgindade e que o motivo do baile era apenas mentira, para o encontro festivo na fonte.

Por fim, a cantiga IX, "Digades, filha, mya filha velida" - motivo inicial deste ensaio - embora não seja a mais plena de significados simbólicos e possibilidades paradigmáticas, revela-se, no entanto, a mais rica em complexidade de vozes do discurso: aqui uma vez mais, aparece a mentira da menina que, agora, diz ter se atrasado na fonte, porque os cervos volviam a água. Uma curiosa sugestão de humor surge ao leitor atento, quando vem a resposta da mãe, que facilmente percebe a mentira da menina, alegando que nunca viu cervos que volvessem as águas do rio e sugerindo, ao mesmo tempo, que não seria ingênua para acreditar em tal desculpa mal pensada.

A primeira consideração que gostaria de evidenciar sobre o todo das cantigas de Pero Meogo, para uma compreensão mais específica da cantiga IX, é o caráter teatralizado e performático dessas cantigas, em detrimento de um aspecto mais legitimamente narrativo. Sem contestar de todo as teses de Azevedo Filho - a de que as nove cantigas de Pero Meogo "apresentam uma forma narrativa, porque nelas se integram e se relacionam os quatro elementos próprios do gênero: personagens, tempo, 
espaço e ação", e a de que "Pero Meogo é um autêntico e longínquo precursor da própria ficção moderna" (teses que considero pertinentes pelo menos para um aspecto da trama romanesca de Meogo $)^{8}$ - quero chamar a atenção, no entanto, para a dimensão mais estruturalmente dramática e teatralizada das referidas cantigas. Claro, é possível vislumbrar ecos longínquos da história amorosa dos personagens de Pero Meogo, e de outros trovadores galego-portugueses, nas novelas sentimentais do séc. 16, como a Menina e moça, de Bernardim Ribeiro, ou os Sete livros de Diana, de Jorge de Montemor (estes, sim, precursores mais diretos da ficção moderna), mas ao mesmo tempo, esses ecos me parecem mais temáticos do que propriamente estruturais. E assim mesmo, os romances do ciclo arturiano servem como referências mais recorrentes e imediatas.

Pensando em considerações de Paul Zumthor (1993) sobre aquilo que ele chama de "literatura" medieval (com aspas), em que a transmissão oral tem implicações bem mais sugestivas do que a tradição escrita, talvez seja possível reconstruir o universo da arte performática dos trovadores que colocavam em cena não uma narrativa, mas um pequeno drama, em que cada jogral (ou "ator") assumia o personagem que lhe cabia na ação. Correia, Dionísio e Gonçalves (in CASTRO, 2001, p. 102), a partir de uma curiosa pontuação de Antonio José Saraiva - a de que "a poesia dos cancioneiros não é lírica mas dramática" -, fazem as seguintes formulações:

Centrando o discurso nas cantigas de amigo galego-portuguesas, alguns estudiosos têm proposto uma leitura e interpretação do corpus a partir de elementos que têm a ver com o modo de transmissão oral, ligado à voz e ao gesto dos intérpretes, à audição, em suma ao espetáculo vivo que a teatralidade da cantiga de amigo eloquentemente sugere. "Teatralidade" e "transmissão oral" são conceitos fundamentais também na mais recente "nota" de A. J. Saraiva sobre a poesia dos cancioneiros. [...]

Ora a inclusão, numa história da literatura portuguesa, de um capítulo sobre a tradição "manuscrita" da poesia trovadoresca profana e religiosa não implica desconhecimento de que a recepção das cantigas esteve ligada à audição, e não à leitura (embora algumas possam ter sido fruídas através da leitura directa), de que a composição terá sido, também em muitos casos, inteiramente oral, de que os textos conservados representam o resultado de um processo de transmissão

${ }^{8}$ A esse respeito, ver Azevedo Filho (1974, p. 87 e 101). 
concretizado em diversas performances orais e de que, portanto, é desejável que se façam esforços para recuperar os valores e as interferências deixadas nos textos.

Também Segismundo Spina (1996, p. 50) já havia chamado a atenção para o fato de que a cantiga paralelística implicava "um jogo de timbres vocálicos determinantes por exigências coreográficas - baile a dois coros, com refrão executado por um solista ou pelos coros em conjunto - depois de cada um executar as estrofes alternadamente"; e por fim, Rodrigues Lapa (1970, p. 151), a respeito da ação que se trava entre os personagens em cena, nas cantigas de amigo, pontua que há "um aspecto deliciosamente dramático que reveste por vezes essa poesia". E é só por esses elementos que se pode compreender, por exemplo, a trama que se desenrola nas cantigas de Pero Meogo. ${ }^{9}$ Colocadas em seqüência, elas se tornam um pequeno drama, com tempo, espaço, personagens e ação dramática. Talvez não seja abusivo imaginar um desempenho teatralizado das cantigas de Meogo, com os músicos compondo o fundo e os jograis representando personagens em cena. E nesse sentido, o foco narrativo da cantiga $\mathrm{V}$, que tem sido definido como um narrador em terceira pessoa, poderia ser tido como uma espécie de coro da ação dramática.

A cantiga IX, que dá seqüência à temática do encontro amoroso das anteriores (V-VIII), coloca no "palco" a representação de uma face ousada da jovem menina fogosa, que contradiz o código ético medieval, enganando a mãe e buscando amores furtivos no meio do campo. Embora não seja uma exceção radical ao corpus das cantigas de amigo dos trovadores galego-portugueses dos sécs. 11-12, o acervo de Pero Meogo - e a cantiga IX, em particular - mantém aspectos originais, ao fazer o retrato audacioso da menina que articular segredos e mentiras. No geral, ainda que possa soar um tanto restritivo, Rodrigues Lapa (1970, p. 151) define duas características fundamentais das cantigas de amigo: "o estado sentimental, criado à namorada pela ausência do amigo; e a situação doméstica da filha sob o poder vigilante da mãe". E de fato, embora haja aí uma infinidade de variantes em torno desses temas, com maior ou menor grau de distanciamento dos núcleos temáticos, os aspectos

\footnotetext{
${ }^{9}$ Rodrigues Lapa (1970, p. 164) lembra ainda que personagens das cantigas de amigo, como a mãe repressora, por exemplo, vão se repetir em dramas posteriores, como na farsa de Quem tem farelos, de Gil Vicente.
} 
apontados por Rodrigues Lapa - ou seja, a saudade e a vigília - são decisivos e permanentes. É claro que o delineamento e a pintura de personagens é que vão possibilitar as variações de drama, conforme o retrato social sugerido por cada trovador. Em geral (e há sempre que relativizar essas afirmações), as jovens retratadas por trovadores são tímidas e recatadas, conforme modelos da ética medieval destinada a mulheres, mas na verdade, uma timidez e um pudor que escondem a pulsão erótica e o desejo reprimido. São mocinhas que revelam seu amor às confidentes (mães, amigas, elementos da natureza), ou a si mesmas, mas que são incapazes de o fazer diante dos namorados, quando então se revestem do recato. O refrão "e moiro d'amor", da cantiga "Vi eu, mha madre, andar", de Nuno Fernandez Torneol (in COHEN, Op. cit., p. 130), que encontra seu eco em tantos versos da época, como no refrão "Ai madre, moiro d'amor!", da cantiga "non chegou, madr', o meu amigo", de D. Dinis, é ilustrativo dos sentimentos da imensa maioria das jovens que representam seus dramas nos cantares trovadorescos. O atrevimento dos amigos, eventualmente registrados por um assédio ou por um convite indecoroso, mostra com graça poética o susto e o pudor das meninas, num misto de medo e desejo, como mostra a cantiga de Roi Queimado:

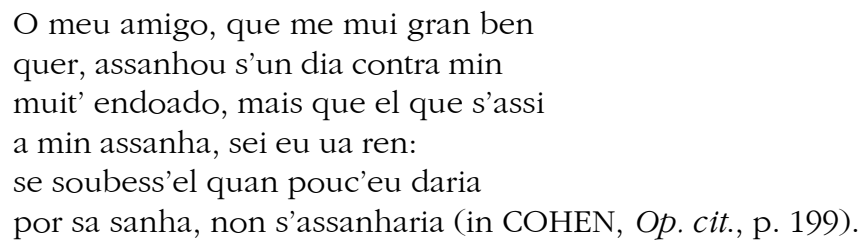

Outra cantiga de João Soares Coelho mostra a menina entre a repulsa e o desejo de corresponder ao convite do amigo, que mandou dizer que chegará para lhe pedir que faça "o que não sabe fazer":

Vedes, amigas, meu amigo ven

e enviou mi dizer e rogar

que lh'aguis'eu de comigo falar

e de tal preito non sei end'eu ren,

e pesa mi que m'enviou dizer

que lhi faça o que non sei fazer (COHEN, Op. cit., p. 171).

João Garcia de Guilhade, um dos que mais se aproximam de Pero Meogo, pela ousadia da festividade erótica e pelo humor insinuante, nos oferece esta cantiga audaciosa, em que o amigo (aliás, o próprio autor 
João Guilhade) pede de sua namorada que tire a cinta, depois a corda da camisa, e por fim, "outra folia" e "outra torpidade":

Vistes, mhas donas, quando noutro dia

o meu amigo comigo falou,

foi mui queixos'e, por que se queixou, dei lh'eu enton a cinta que tragia, mais el demanda m' or' outra folia

E vistes que nunca tal cousa visse:

por s'ir queixar, mhas donas, tan sen guisa, fez mi tirar a corda da camisa

e dei lh'eu dela ben quanta m'el disse, mais el demanda mh al, que non fexisse

Sempr'averá don Johan de Guilhade, mentr'el quiser, amigas, das mhas dõas, ca ja m' end' el muitas deu e mui bõas; des i terrei lhi sempre lealdade, mais el demanda m'outra torpidade (COHEN, Op. cit., p. 235).

A personagem central das cantigas de Pero Meogo - a menina que chora a ausência do amado, que se confidencia com a mãe e com os cervos do monte, que mente e dissimula, e por fim, que se entrega às delícias amorosas com o amigo - ainda que não seja exatamente uma exceção a algumas outras jovens retratadas por trovadores, mostra-se a contraparte de um discurso legítimo do padrão comportamental das mulheres medievais. Sua ruptura de valores, suas decisões arrojadas servem como uma espécie de antítese das idealizadas e distantes personagens femininas das cantigas de amor. Seu gesto é quase um contradiscurso no universo ético e sexual atribuído às mulheres da Idade Média peninsular, o que, de certa forma, levanta especulações sobre as origens e os propósitos das cantigas de amigo.

A respeito das origens do trovadorismo, e das relações entre essas origens e suas razões literárias, nada posso acrescentar aos estudos de Rodrigues Lapa $(1965,1970)$, senão uma intuição histórica de que os cantares de amigo serviam como um tipo de palinódia das cantigas de amor, uma retratação das severidades morais e da dimensão espiritualizante das damas ali celebradas, por uma engenhosa estratégia masculina de atribuição do discurso à própria voz feminina. Em outros termos, a menina das cantigas de amigo diz aquilo que uma dama das cantigas de 
amor não poderia dizer, e que é justamente aquilo que o jovem trovador gostaria de ouvir.

É certo que os cantares de amigo não podem ter servido exatamente como resposta ao universo platônico e artificioso das cantigas de amor, já que grande parte dos estudiosos recentes concorda que os cantares de amigo sejam manifestações legitimamente antóctones e talvez mais antigas do que o gênero de amor. Hernani Cidade (1972, p. VI) toma as cantigas de amigo peninsulares como fenômeno de um "húmus nacional", e Antônio José Barreiros (1997, p. 72), em síntese historicista e filológica das discussões promovidas no séc. 20, esclarece que os cantares de amigo nasceram de tradição diversa da poesia provençal, e que quem arrastou os portugueses e os galegos para o novo gênero "foi, sem dúvida, a poesia popular da região". De fato, o comportamento da personagem de Pero Meogo, da forma como vimos, não poderia ter recebido reflexos provençais, e só poderia ser visto mesmo como a antítese deles, o que não quer dizer que as cantigas de amigo tenham servido como uma resposta imediata (em sentido cronológico do termo) às severidades morais de uma face específica das mulheres medievais retratadas por trovadores. Estes, que aparecem, ao mesmo tempo, em diversos cancioneiros, exercitaram ambos os gêneros e foram capazes de reformular condutas femininas, quando transitavam de um para outro.

Rodrigues Lapa, que compilou estudos históricos sobre as origens do trovadorismo, põe em pauta as mais diversas teses formuladas desde o séc. 19, para concluir que certas hipóteses (como a tese da origem árabe das cantigas de amigo, ou a das origens heréticas e albigenses nos cantares de amor) foram imaginações românticas que a filologia hoje mostra não ter fundamento, ${ }^{10}$ afirmação, aliás, perigosa, diante das complexidades históricas por ele mesmo evidenciadas. Hernani Cidade (Op. cit., p. VIII-XIII), por sua vez, embora em estudo bastante resumido, menciona as espécies de poesia árabe e judaica (as moaxahas, o zéjen), sem lhes contestar a validade para discutir origens. ${ }^{11}$ Mas afora o problema

${ }^{10}$ Ver Rodrigues Lapa, 1965, pp. 170-176, 202-236; e 1970, pp. 29-102.

${ }^{11} \mathrm{O}$ problema da tese árabe nas origens do trovadorismo, que prefiro não discutir em sua amplitude, sobretudo porque não compõe os interesses deste ensaio, foi exaustivamente debatido. Saraiva e Lopes (2005, pp. 62-63), seguindo a filologia de Lapa, recusam as influências árabes na formulação das cantigas de 
das origens, que permanece inconcluso, apesar de descobertas recentes e da expansão de material histórico mais farto, o fato é que - pelo menos nos cancioneiros galego-portugueses - um diálogo imaginário, ou antes, uma possível relação imaginária parece eclodir das cantigas de amor e de amigo, quando ambos os gêneros são colocados lado a lado, como se ambos fossem um para o outro um exercício de oposições e palinódias. A menina das cantigas de amigo responde a possibilidades diversas da dama de amor, relativizando-lhe a severidade, o distanciamento, a impenetrabilidade psicológica, propondo agora a simulação de uma jovem (portanto, não mais uma dama de elevado status social) que sente, que ama, que chora saudades e - para o caso de Pero Meogo - que é capaz de mentir e dissimular para resolver o desejo confesso do encontro amoroso.

É bastante curiosa a consideração de Rodrigues Lapa (1970, p. 151) de que, na cantiga de amigo, "a dona cai do seu pedestal de adoração e torna-se igual do homem, perde em sublimidade, mas ganha em humaníssimo encanto". Se é verdade o fato de que as cantigas de amor resumiam os exercícios estóicos do amor cortês e que este se resolvia pelo domínio e controle absoluto das paixões e do sentimento amoroso, como prática comum entre cavaleiros, nobres e estudantes, é possível entrever aí um conjunto de valores morais repressivos cujo código é o investimento no amor que se dá sem merecimento, sem retorno. O amor cortês era, portanto, uma disciplina civilizatória dos meios aristocráticos e uma prática de inibição das investidas sexuais. Assim sendo, como explica Georges Duby (1988, p. 72), essa prática era como um jogo, um torneio, de que os plebeus estavam excluídos. ${ }^{12}$

amigo e de amor. Alexandrian (1993, pp. 41-42), no entanto, diz que Guilherme IX de Poitiers, duque de Aquitânia, tido como o primeiro trovador do amor cortês, mudou seu estilo licencioso para a lírica cortês depois de um contato com os árabes, numa viagem às Cruzadas. Jacques Sole (in A.A.V.V., 1992, p. 82), igualmente explica que, para as raízes trovadorescas, "a influência da poesia neolatina dos estudantes, os 'aprendizes errantes' (clerici vagi) do século X é longínqua. As influências muito variadas do folclore meridional, da brilhante civilização árabe andaluza e da moral cavalheiresca estão muito mais próximas".

${ }^{12}$ As referências sobre o amor cortês como prática civilizatória, e suas conseqüências na arte dos trovadores, são extensas, e no caso especial dos historiadores das mentalidades, explicam que o jogo da prática cortês não pressupõe exatamente uma promoção da mulher, já que esta serve apenas 
A simulação da menina das cantigas de amigo, que substitui a dama cortês e que a faz cair do pedestal, cantando paixões próprias e confissões íntimas, num discurso em primeira pessoa, é uma prática imaginária fabulosa de realização erótica, por parte de um discurso masculino, como forma de se desvencilhar dos rigores estóicos do amor cortês platônico. Nas cantigas de amigo, tudo é erotismo, festividade, rejúbilo sensual, mesmo em algumas em que a tônica é a saudade: as jovens celebram seu prazer e a beleza do corpo feminino diante da natureza ou nas danças festivas: "por quanto ben m'i Nostro Senhor fez;/ fez me fremosa e de mui bon prez", diz a amiga, numa cantiga de João Garcia de Guilhade. Diz outra, num texto de Airas Nunes:
Bailemos nós já todas três, ai amigas, so aquestas avelaneiras froridas, e quen for velida, como nós, velidas, se amigo amar, so aquestas avelaneira froridas verrá bailar.

É por essas considerações todas que se pode compreender a cantiga IX, de Pero Meogo que, como já disse, se não é a mais rica em sugestões simbólicas, é das mais elaboradas em complexidade de vozes e discursos que se entrecruzam. Mais que um simples diálogo entre a mãe e a filha, o texto sugere invocações e possibilidades discursivas mais complicadas, a começar pela mentira da menina, exposta a partir da terceira estrofe, que já deve ser percebida pelo leitor, ou no caso, pelo ouvinte-expectador, se pensarmos num receptor medieval, para quem as cantigas eram encenadas. Embora a dissimulação da menina seja

como uma metonímia do senhor vassálico, o que pressupõe, ao contrário, o amor cortês como um exercício civilizatório de devoção ao senhor, por meio de uma investida sobre o objeto que o substitui por uma estratégia imaginária, ou seja, a dama. Nesse sentido, o amor cortês serve também como um jogo controlador dos ímpetos, um exercício estóico de domínio das paixões, por meio de um discurso platônico do amor; portanto, uma vez mais, uma promoção social e cultural dos jovens aristocráticos, e não das mulheres. Sobre essa questão, remeto o leitor às seguintes leituras: Marchello-Nizia (1981, p. 969-982), Duby (in DUBY \& PERROT, 1990, vol. II, pp. 331-351) e Régnier-Bohler (in LE GOFF \& SCHMIDT, 2002, vol. I, p. 47-55). 
desvelada apenas na $5^{\underline{a}}$ estrofe ("- Mentir, mya filha, mentir por amigo"), com a réplica da mãe que facilmente percebe a fragilidade da mentira, o ouvinte - mesmo aquele que não teve acesso às demais cantigas do trovador - já é capaz de reconhecer os engenhosos mecanismos da jovem, se se atentar para o refrão, "Os amores ey". Sabe-se que a amiga engana sua mãe, inventando a desculpa da presença de cervos no rio, mas há uma voz interna que não é "ouvida" pela mãe, mas a que o ouvinte-expectador tem acesso, por uma espécie de "à parte" dos dramas medievais e renascentistas. A jovem vai simulando a mentira, mas sua voz interior, ou antes, sua consciência, vai lhe denunciando o desejo íntimo, que é "pensado", mas que não pode ser dito: "Os amores ey" (estou amando, estou apaixonada). Desde a primeira formulação da pergunta da mãe, de certa forma já antecipada pela filha (que chegou tarde e sabe que será indagada), a menina se denuncia por uma consciência culposa, e que é representada pela persistência de um refrão denunciador. ${ }^{13}$ É como se tivéssemos três vozes implicadas aí dentro: a voz da mãe, a voz da filha e a voz de uma consciência que se denuncia. É como se a filha, antes mesmo de criar o artifício da mentira, já sentisse o peso dessa consciência, que lhe perturba o ânimo, como se o raciocínio tivesse como pressuposto a seguinte formulação: estou amando, entreguei-me a meu amigo, sou culpada disso, mas minha mãe não poder saber. A própria mentira (e outros críticos já haviam percebido isso) tem caráter denunciador, uma vez que identificamos, conforme sugestões de Azevedo Filho, a imagem do cervo com o elemento masculino. São curiosas formulações psicanalíticas que lembram o lapsus linguae, por exemplo, em que o indivíduo não quer dizer uma coisa, mas já disse.

Talvez não seja abusivo pensar aqui numa encenação desta cantiga por jograis e músicos peninsulares do séc. 13, cada um assumindo papéis diversos dessas vozes discursivas. Se o refrão pode funcionar como um "à parte" típico do teatro medieval e renascentista, em que o "ator", ou jogral, sai de sua máscara, de sua persona, para tornar-se um súbito confidente da platéia, o efeito só pode ter um impacto humorístico, com

\footnotetext{
${ }^{13}$ Azevedo Filho (1974, p. 41) já havia observado estratégia semelhante, no refrão da cantiga I, em que a filha diz que deixará de ir ao encontro com o namorado na fonte, se a mãe se opuser: "Em plano literal, ela diz que mentirá ao amigo, em respeito à mãe (função conjuntiva). Mas no refrão, insinua-se que ela está mais empenhada em ir ao encontro do que em obedecer à mãe (função disjuntiva)".
} 
a mãe representando (pelo menos a princípio) o papel da enganada, numa farsa de cuja simulação a própria platéia toma parte. Rimos porque a menina inventa uma mentira para a mãe, enquanto dá outra versão para o público, deixando-se flagrar num ato imprevisto e inevitável de consciência revelada. O momento da revelação da verdade, encenado pela réplica da mãe que descobre a farsa, muda os rumos da trama, e agora é a menina que se vê em maus lençóis, quando flagrada pela astúcia da mãe. É ela agora o motivo do riso.

Por tudo isso, percebe-se uma divertida estratégia de humor na cantiga IX de Pero Meogo, o que de resto, torna o todo de seu pequeno "drama" de nove cantigas um composto de elementos diversos, de tonalidades diversas, que vai do lírico ao dramático, do elegíaco ao humorístico, do erótico ao sentimental. A elegia das cantigas III e IV, por exemplo, contrasta com os eflúvios eróticos das cantigas V e VI, que por sua vez, se diferenciam das carregadas sugestões simbólicas da cantiga VIII. É bastante sugestivo que Pero Meogo tenha concluído seu drama, com desfecho tão divertido e pleno de uma festividade sensual e campestre, como que antecipando as narrativas eróticas de Boccaccio ${ }^{14}$ ou as comédias igualmente sensuais da primeira fase de Shakespeare. $\mathrm{Na}$ cantiga em análise, a mãe, enquanto elemento repressor, apesar de evidenciar sua autoridade e exercer o ofício de seu cargo, percebe a inevitabilidade de sua vigília. O desfecho da trama, a julgar pela tonalidade risonha e festiva, parece nos deixar com a sensação de uma celebração dos divertimentos eróticos das traições e das tradições pagãs, uma celebratio vitae, em que a vida, o amor, a sensualidade e o desejo dissimulam os seus ímpetos com velhas artimanhas contra os códigos morais. Como sugerem as "verdes ervas", os bailes, os animais silvestres e as fontes frias em que se banham os cabelos, a explosão de prazer e erotismo parece corresponder às festas primaveris no campo e aos ardores e anseios da vida que desabrocha. Bastante ousado para um monge.

\footnotetext{
${ }^{14}$ Considero Boccaccio um dos poetas e narradores que, no fim da Idade Média, mais souberam lidar com o universo do erotismo feminino, nesse seu projeto de retratar as mulheres como almas sinceras e desejosas, em sua intimidade. Basta lembrar a narrativa intimista e confessional de Fiammetta, na Elegia di madonna Fiammetta, uma espécie de retomada inaugural e vultuosa das cantigas de amigo, no séc. 14, em formato humanista e em dimensões romanescas mais complexas.
} 
Para terminar, já que mencionei Boccaccio como um tipo de herdeiro indireto das experimentações de Pero Meogo, quero deixar o leitor com o delicioso e divertido soneto introdutório das Rime (1999, p. 33), do autor do Decameron, como exemplo fantástico de humor e erotismo combinados. Nele, três mocinhas angelicais descansam numa fonte, falando de seus amores, em típica cena de idílio cortesão e platônico, quando uma delas pergunta para onde fugiriam, se por ventura os seus amados por ali chegassem. Para fechar o diálogo, a outra quebra a expectativa de recato e pudor espiritual, já antecipados pelo leitor, e responde que bem pouco sábia seria aquela que fugisse:

$$
\begin{aligned}
& \text { Intorn'ad una fonte, in un pratello } \\
& \text { di verdi erbette pieno e di bei fiori, } \\
& \text { sedean tre angiolette, i loro amori } \\
& \text { forse narrando, e a ciascuna 'l bello } \\
& \text { viso adombrava un verde ramicello } \\
& \text { ch'i capei d'or cingea, al qual di fuori } \\
& \text { e dentro insieme i dua vaghi colori } \\
& \text { avolgeva su suave venticello. } \\
& \text { E dopo alquanto l'una alle due disse } \\
& \text { (com'io udi'): "Deh, se per avventura } \\
& \text { di ciascuna l'amante or qui venisse, } \\
& \text { fuggiremo noi quinci per paura?" } \\
& \text { A cui le due risposer: "Chi fugisse, } \\
& \text { poco savia saria, cotal ventura!" }
\end{aligned}
$$

\section{Referências Bibliográficas}

AZEVEDO FILHO, Leodegário A. de. As cantigas de Pero Meogo. Rio de Janeiro: Edições Gernasa, 1974.

. Três ensaios de literatura medieval galego-portuguesa. Rio de Janeiro: Ágora da Ilha, 2000.

BARREIROS, Antonio José. História da literatura portuguesa. Vol. 1: sécs. XIIXVIII. Braga: Bezerra Editora, 1997.

BOCCACCIO, Giovanni. Rime. Ed. de Vittore Branca. Milano: Mondadori, 1992.

CANCIONEIRO da Biblioteca Nacional: Colocci-Brancuti. 1. Reprodução facsimilada. Lisboa: Biblioteca Nacional/ Imprensa Nacional - Casa da Moeda, 1982). 
CASTRO, F. L. Ver CORREIA, DIONÍSIO e GONÇALVES.

CIDADE, Hernani (Org.). Poesia medieval. I. Cantigas de amigo. 5. ed. Lisboa: Seara Nova, 1972.

COHEN, Rip. 500 cantigas d'amigo. Porto: Campo das Letras, 2003.

CORREIA, Ângela M.; DIONÍSIO, João M.; GONÇALVES, Maria Elsa. A poesia lírica galego-portuguesa. In: CASTRO, Francisco Lyon de (ed.). História da literatura portuguesa. Vol. 1: Das origens ao Cancioneiro Geral. Lisboa: Publicações Alfa, 2001. p. 101-161.

DUBY, Georges. A Idade Média: uma idade do homem. Trad. Maria Assunção Santos. Lisboa: Teorema, s. d.

. O modelo cortês. In: DUBY, Georges; PERROT, Michelle. História das mulheres. Vol. 2: A Idade Média. Porto: Edições Afrontamento, s. d. p. 331-351.

LANCIANI, Giulia; TAVANI, Giuseppe (Org.). Dicionário da literatura medieval galega e portuguesa. Lisboa: Caminho, 1993.

MARCHELLO-NIZIA, Christiane. Amour courtois, sociétés masculines et figures du pouvoir. Annales E.S.C., 36, (6), p. 969-982, 1981.

REGNIER-BOHLER, Danielle. Amor cortesão. In: LE GOFF; SCHMITT, JeanClaude. Dicionário temático do ocidente medieval. Trad. (coord.) de Hilário Franco Jr. Bauru/ São Paulo: EDUSC/ Imprensa Oficial do Estado, 2002. v. I, p. 47-55.

RODRIGUES LAPA, Manuel. Lições de literatura portuguesa: época medieval. 7. ed. Coimbra: Coimbra Editora, 1970.

. Miscelânea de língua e literatura portuguesa medieval. Rio de Janeiro: Instituto Nacional do Livro/ Ministério da Educação e Cultura, 1965.

SÁNCHEZ, José Maria González-Serna. Notas a una cantiga de Pero Meogo. Revista de Aula de Letras, Humanidades y Enseñanza. Disponível em: <http:/ /www.auladeletras.net/revista/articulos/serna.pdf $>$. Acesso em 26 de maio de 2007.

SARAIVA, Antonio José; LOPES, Óscar. História da literatura portuguesa. 17. ed. Porto: Porto Editora, 2005.

SOLÉ, Jacques. Os trovadores e o amor-paixão. In: A.A.V.V. Amor e sexualidade no Ocidente. Trad. Ana Maria Capovilla, Horácio Goulart e Sueli Bastos. Porto Alegre: L\&PM, 1992. 
SPINA, Segismundo. A lírica trovadoresca. São Paulo: Editora da Universidade de São Paulo, 1996.

VASCONCELLOS, Carolina Michäelis de (Ed.). Cancioneiro da Ajuda. Reimpressão da edição de Halle (1904). Lisboa: Imprensa Nacional/ Casa da Moeda, 1990 (2 vols.).

ZUMTHOR, Paul. A letra e a voz: a "literatura" medieval. Trad. Amálio Pinheiro e Jerusa P. Ferreira. São Paulo: Companhia das Letras, 1993.

\section{Resumo}

O presente artigo pretende analisar a cantiga "Digades filha mha filha velida", de Pero Meogo (Cancioneiro da Biblioteca Nacional 1192 e Cancioneiro da Biblioteca Vaticana 797), que faz parte dos cancioneiros dos trovadores galego-portugueses medievais. O poema será analisado em conformidade com as outras cantigas de Pero Meogo, buscando-se os elementos eróticos e sugestivos, e evidenciando as possibilidades teatrais e performáticas nele contidas.

\section{Abstract}

The present paper aims at analyzing Pero Meogo's song "Digades filha mha filha velida" (Cancioneiro da Biblioteca Nacional 1192 and Cancioneiro da Biblioteca Vaticana 797), which makes part of the medieval GalicianPortuguese troubadour songbooks. The poem will be analyzed according to Pero Meogo's other songs, by searching the erotic and suggestive elements and by demonstrating the performance and theatrical possibilities contained in it. 


\section{Anexo 1}

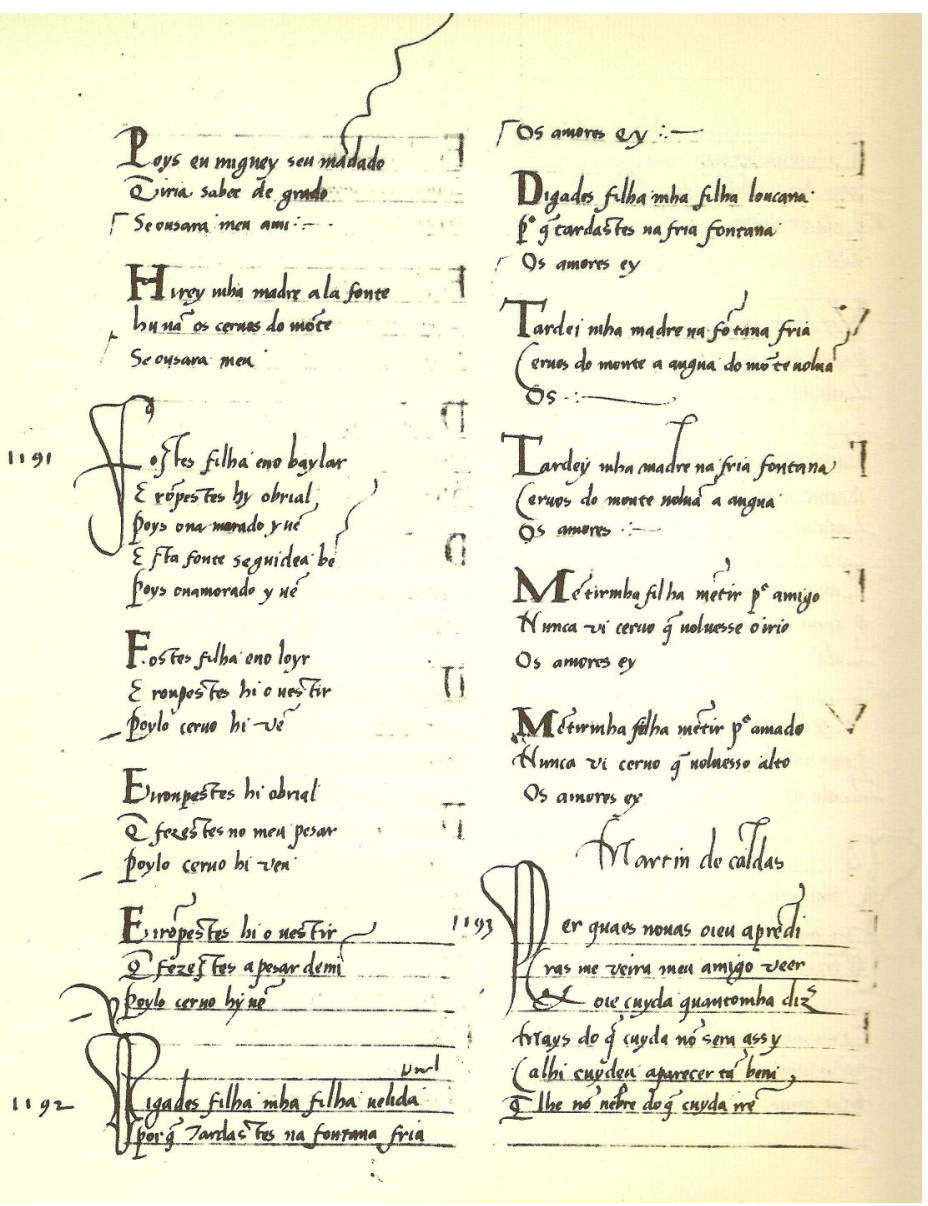

Fig. 1. Códice COD. 10991, CBN, da Biblioteca Nacional de Lisboa, fólio 254, com a cantiga "Digades filha mha filha velida" (n. 1192), de Pero Meogo. 


\section{Anexo 2}

A cantiga IX de Pero Meogo, na versão de Cohen (2003, p. 425):

- Digades, filha, mha filha velida, por que tardastes na fontana fria?

(- Os amores ei)

Digades, filha, mha filha louçana, por que tardastes na fria fontana?

(- Os amores ei)

- Tardei, mha madre, na fontana fria, cervos do monte a augua volvian;

(- Os amores ei)

Tardei, mha madre, na fria fontana, cervos do monte volvian a augua;

(- Os amores ei)

- Mentir, mha filha, mentir por amigo, nunca vi cervo que volvesse o rio;

(- Os amores ei)

Mentir, mha filha, mentir por amado, nunca vi cervo que volvesse o alto;

(- Os amores ei) 